\title{
Correction to: Mediterranean diet in axial spondyloarthritis: an observational study in an Italian monocentric cohort
}

\author{
Francesca Ometto ${ }^{1}$, Augusta Ortolan ${ }^{1 \dagger}$, Davide Farber ${ }^{1 \dagger}$, Mariagrazia Lorenzin' ${ }^{1}$, Giulia Dellamaria², \\ Giacomo Cozzi ${ }^{1}$, Marta Favero ${ }^{1,3}$, Romina Valentini ${ }^{2}$, Andrea Doria ${ }^{1}$ and Roberta Ramonda ${ }^{1 *}$
}

Correction to: Arthritis Res Ther 23, 219 (2021)

https://doi.org/10.1186/s13075-021-02600-0

Following publication of the original article [1], the authors reported an error in the Abstract section under Conclusions.

The line "Patients with a lower BMI and older patients are $\mathbf{L E S S}$ prone to modify their diet towards the Mediterranean diet following nutritional advice" should be corrected to the following "Patients with a lower BMI and older patients are MORE prone to modify their diet towards the Mediterranean diet following nutritional advice".

The original article [1] has been updated.

\section{Author details}

'Department of Medicine - DIMED, Rheumatology Unit, University of Padova, Via Giustiniani 2, 35,128, Padua, Italy. ${ }^{2}$ Department of Medicine - DIMED, Dietetics and Clinical Nutrition Unit, University of Padova, Padua, Italy. ${ }^{3}$ Medicina Interna I^, Cà Foncello Hospital, Treviso, Italy.

Published online: 11 November 2021

\section{Reference}

1. Ometto F, Ortolan A, Farber D, et al. Mediterranean diet in axial spondyloarthritis: an observational study in an Italian monocentric cohort. Arthritis Res Ther. 2021;23:219. https://doi.org/10.1186/s13075-021-02600-0. original author(s) and the source, provide a link to the Creative Commons licence, and indicate if changes were made. The images or other third party material in this article are included in the article's Creative Commons licence, unless indicated otherwise in a credit line to the material. If material is not included in the article's Creative Commons licence and your intended use is not permitted by statutory regulation or exceeds the permitted use, you will need to obtain permission directly from the copyright holder. To view a copy of this licence, visit http://creativecommons.org/licenses/by/4.0/. The Creative Commons Public Domain Dedication waiver (http://creativeco mmons.org/publicdomain/zero/1.0/) applies to the data made available in this article, unless otherwise stated in a credit line to the data. 